\title{
Role of antibiotic stress in phenotypic switching to persister cells of antibiotic- resistant Staphylococcus aureus
}

\author{
Jirapat Dawan', Shuai Wei ${ }^{1,2}$ and Juhee $\mathrm{Ahn}^{1^{*}}$ (D)
}

\begin{abstract}
Purpose: This study was designed to evaluate phenotypic and genotypic properties of persister cells formed by Staphylococcus aureus ATCC 15564 (SA ${ }^{\text {WT }}$ ), oxacillin-induced S. aureus (SA ${ }^{\text {OXA }}$ ), ciprofloxacin-induced S. aureus (SA ${ }^{\text {CIP }}$, and clinically isolated multidrug-resistant S. aureus CCARM 3080 (SA $\left.{ }^{\text {MDR }}\right)$.

Methods: The dose-dependent biphasic killing patterns were observed for $S A^{W T}, S A^{O X A}, S A^{C I P}$, and SAMDR in response to twofold minimum inhibitory concentrate (MIC) of ciprofloxacin. The surviving cells of SA ${ }^{W T}$, SA ${ }^{\text {OXA }}$, $S A^{C I P}$, and $S A^{M D R}$ after twofold MIC of ciprofloxacin treatment were analyzed using a metabolic-based assay to estimate the fractions of persister cells.

Results: The least persister formation was induced in $\mathrm{SA}$ CIP after twofold MIC of ciprofloxacin treatment, showing $58 \%$ of persistence. The lowest fitness cost of resistance was observed for the recovered persister cells of SA ${ }^{\text {CIP }}$ (relative fitness $=0.95$ ), followed by SAMR (relative fitness $=0.70$ ), while the highest fitness cost was observed for $\mathrm{SA}^{\mathrm{WT}}$ (relative fitness $=0.26$ ). The mRNA transcripts were analyzed by RT-PCR assay in recovered persister cells preincubated with ciprofloxacin. The highest expression levels of stress-related genes (dnaK and groEL) and efflux pump-related genes (mepR, norA, and norB) were observed in the recovered persister cells of SA ${ }^{\text {OXA }}$ and SA ${ }^{\mathrm{MDR}}$. Conclusion: This study provides valuable information for understanding crosstalk between antibiotic resistance, tolerance, and persistence in different antibiotic-resistant $S$. aureus strains.
\end{abstract}

Keywords: Staphylococcus, Persistence, Resistance, Tolerance, Ciprofloxacin

\section{Introduction}

Over the past few decades, the overuse and misuse of antibiotics have accelerated the emergence and spread of antibiotic-resistant Staphylococcus aureus, specifically methicillin-resistant S. aureus (MRSA) (Deguchi et al. 2018). The frequent use of antibiotics potentially exerts selection pressure on $S$. aureus, resulting in an increased resistance to multiple antibiotics (Sakoulas et al. 2006). MRSA is the leading cause of hospitaland community-acquired infections, including sepsis, bacteremia, osteomyelitis, and endocarditis (Lowy 1998; Conlon 2014). The antibiotic selection pressure can provide a survival strategy for MRSA conferring

\footnotetext{
* Correspondence: juheeahn@kangwon.ac.kr

${ }^{1}$ Department of Medical Biomaterials Engineering and Institute of Bioscience and Biotechnology, Kangwon National University, Chuncheon, Gangwon 24341, Republic of Korea

Full list of author information is available at the end of the article
}

fitness benefits and eventually lead to treatment failure (Sahukhal et al. 2017). The bacterial response to antibiotic stress causes phenotypic switching from normal to persister, tolerant, and resistant cells (Balaban et al. 2004; Lewis 2007; Kester and Fortune 2014). Persistence, tolerance, and resistance are mainly characterized by bacterial growth rates in the presence of antibiotic stress. Persistence is a metabolically inactive state that bacterial sub-population enters a dormant state under stressful conditions. Tolerance is a state that slow-growing bacteria dominate the population, while resistance is defined as the ability of bacteria to grow at the same rate in the presence of antibiotic stress (Fernández-García et al. 2018). Among them, however, the persistence has been relatively overlooked in the evolution of antibiotic resistance in bacteria. 
Recently, the persistence has received growing attention as a new approach for controlling antibioticresistant bacteria (Fernández-García et al. 2018). The persistence is reversible phenotypic switching associated with heterogeneous bacterial populations (Balaban et al. 2004; Patra and Klumpp 2013). Persister cells also play an important role in the emergence of antibiotic resistance, resulting in antibiotic treatment failure (Dörr et al. 2010). Factors affecting the persister cell formation include efflux pump systems, SOS response, energy production, signal transduction, stringent response, protein degradation, and toxin-antitoxin (TA) systems (Lewis 2010; Fasani and Savageau 2013; Harms et al. 2016; Sahukhal et al. 2017). Understanding the characteristics of persistence is essential to optimize antibiotic chemotherapy (Girgis et al. 2012). However, the precise mechanism of persistence is not clearly understood. Therefore, the objectives of this study were to evaluate the phenotypic switching to persister cells of antibiotic-resistant $S$. aureus when exposed to a high level of ciprofloxacin.

\section{Materials and methods}

\section{Bacterial strains and culture conditions}

Strains of Staphylococcus aureus ATCC 15564 (SA ${ }^{\mathrm{WT}}$ ) and clinically isolated multidrug-resistant $S$. aureus CCARM $3080\left(\mathrm{SA}^{\mathrm{MDR}}\right)$ were purchased from the American Type Culture Collection (ATCC, Manassas, VA, USA) and the Culture Collection of Antibiotic Resistant Microbes (CCARM, Seoul, Korea), respectively. The strains were cultured in tryptic soy broth (TSB; Difco, Becton, Dickinson and Co., Sparks, MD, USA) at $37{ }^{\circ} \mathrm{C}$ for $20 \mathrm{~h}$. The cultured cells were harvested by centrifugation at $3000 \times g$ for $20 \mathrm{~min}$ at $4{ }^{\circ} \mathrm{C}$, washed twice with phosphate-buffered saline (PBS; pH 7.2), and then diluted with TSB prior to use.

\section{Stepwise selection assay}

$\mathrm{SA}^{\mathrm{WT}}$ cells were exposed to oxacillin and ciprofloxacin to obtain experimentally induced antibiotic-resistant $S$. aureus. The minimum inhibitory concentrate (MIC) values of oxacillin and ciprofloxacin are 0.25 and $0.5 \mu \mathrm{g} / \mathrm{ml}$, respectively. According to the serial passage method (Birošová and Mikulášová 2009), the concentrations of oxacillin and ciprofloxacin were increased from 0.125 (a half the MIC) to $8 \mu \mathrm{g} / \mathrm{ml}$ and from 0.25 (a half the MIC) to $32 \mu \mathrm{g} / \mathrm{ml}$, respectively. The oxacillin- and ciprofloxacin-induced isogenic $\mathrm{SA}^{\mathrm{WT}}$ strains were assigned to oxacillin-induced $S$. aureus $\left(\mathrm{SA}^{\mathrm{OXA}}\right)$ and ciprofloxacin-induced $S$. aureus $\left(\mathrm{SA}^{\mathrm{CIP}}\right)$, respectively. The antibiotic-induced resistance in $\mathrm{SA}^{\mathrm{OXA}}$ and $\mathrm{SA}^{\mathrm{CIP}}$ were extensively cultured for 10 passages in antibiotic-free TSB to confirm the stability of antibiotic resistance.

\section{Antibiotic susceptibility assay}

The antibiotic susceptibilities of $\mathrm{SA}^{\mathrm{WT}}, \mathrm{SA}^{\mathrm{OXA}}, \mathrm{SA}^{\mathrm{CIP}}$, and $\mathrm{SA}^{\mathrm{MDR}}$ to the selected antibiotics were determined according to the Clinical Laboratory Standards Institute (CLSI) broth microdilution assay (CLSI 2019). Antibiotic stock solutions were prepared by dissolving in distilled water (ampicillin, cephalothin, gentamicin, oxacillin, and vancomycin) and glacial acetic acid (ciprofloxacin) to obtain a final concentration of $10.24 \mathrm{mg} / \mathrm{ml}$. Each antibiotic stock solution was serially (1:2) diluted in 96-well microtiter plates and then inoculated with $\mathrm{SA}^{\mathrm{WT}}$, $\mathrm{SA}^{\mathrm{OXA}}, \mathrm{SA}^{\mathrm{CIP}}$, or $\mathrm{SA}^{\mathrm{MDR}}\left(10^{5} \mathrm{CFU} / \mathrm{ml}\right.$ each). The inoculated plates were incubated at $37^{\circ} \mathrm{C}$ for $18 \mathrm{~h}$. The lowest antibiotic concentrations with no visible growth were defined as minimum inhibitory concentration (MIC).

\section{Induction of persister cells}

To induce persister cells, $\mathrm{SA}^{\mathrm{WT}}, \mathrm{SA}^{\mathrm{OXA}}, \mathrm{SA}^{\mathrm{CIP}}$, and $\mathrm{SA}^{\mathrm{MDR}}$ cells were exposed to different concentrations (1/2 to twofold MIC) of ciprofloxacin. After $24 \mathrm{~h}$ of incubation at $37^{\circ} \mathrm{C}$, the cells were collected by centrifugation at $3000 \times g$ for $20 \mathrm{~min}$ at $4{ }^{\circ} \mathrm{C}$, serially (1:10) diluted, and plated on TSA using an Autoplate Spiral Plating System (Spiral Biotech Inc., Norwood, MA, USA). The plates were incubated at $37^{\circ} \mathrm{C}$ for $24-48 \mathrm{~h}$ to enumerate viable cells. In addition, the harvested cells were further analyzed to investigate phenotypic and genotypic properties of persister cells.

\section{Measurement of persister cells}

The metabolic activities of $\mathrm{SA}^{\mathrm{WT}}, \mathrm{SA}^{\mathrm{OXA}}, \mathrm{SA}^{\mathrm{CIP}}$, or $\mathrm{SA}^{\mathrm{MDR}}$ cells exposed to twofold MIC of ciprofloxacin at $37^{\circ} \mathrm{C}$ for $24 \mathrm{~h}$ were measured using a WST kit (iNtRON Biotechnology, MA, USA). In brief, the harvested cells $(100 \mu \mathrm{l}$ each) were placed in 96-well plates and mixed with $10 \mu \mathrm{l}$ of the pre-warmed mixture of electroconnecting solution $(10 \mu \mathrm{l})$ and WST-1 reagent $(100 \mu \mathrm{l})$. The plates were incubated for $5 \mathrm{~h}$. The absorbance was measured at $440 \mathrm{~nm}$ using a microplate reader (BioTek Instruments, Inc., Winooski, VT, USA) with a reference wavelength of $650 \mathrm{~nm}$. A standard curve was prepared at serially diluted controls from $10^{8}$ to $10^{2} \mathrm{CFU} / \mathrm{ml}$ and measured as described above.

\section{Estimation of fitness cost of resistance}

The relative fitness was estimated to evaluate the pleiotropic cost of resistance of $\mathrm{SA}^{\mathrm{WT}}, \mathrm{SA}^{\mathrm{OXA}}, \mathrm{SA}^{\mathrm{CIP}}$, or $\mathrm{SA}^{\mathrm{MDR}}$ cells exposed to twofold MIC of ciprofloxacin at $37{ }^{\circ} \mathrm{C}$ for $24 \mathrm{~h}$. The persister cells were cultured at $37^{\circ} \mathrm{C}$ for $24 \mathrm{~h}$ in antibiotic-free TSB. The relative fitness was expressed as the ratio of the growth $\left(\mathrm{OD}_{600}\right)$ of persister cells to that of control. 


\section{Disk diffusion assay}

The ciprofloxacin-exposed $\mathrm{SA}^{\mathrm{WT}}, \mathrm{SA}^{\mathrm{OXA}}, \mathrm{SA}^{\mathrm{CIP}}$, and $\mathrm{SA}^{\mathrm{MDR}}$ cells were regrown in fresh TSB at $37{ }^{\circ} \mathrm{C}$ for 20 $\mathrm{h}$, which were used to evaluate the antibiotic susceptibilities by the disk diffusion test. The cultured cells were spread on TSA plates and the plates dried for $5 \mathrm{~min}$. Antibiotic disks, including cefotaxime (CEF; $30 \mu \mathrm{g}$ ), cephalothin (CEP; $30 \mu \mathrm{g})$, chloramphenicol (CHL; 30 $\mu \mathrm{g})$, ciprofloxacin (CIP; $5 \mu \mathrm{g}$ ), erythromycin (ERY; 15 $\mu \mathrm{g}$ ), levofloxacin (LEV; $5 \mu \mathrm{g}$ ), and meropenem (MER; 10 $\mu \mathrm{g})$, were placed onto TSA. After incubation at $37^{\circ} \mathrm{C}$ for $24 \mathrm{~h}$, the diameters of clear zone were measured using a digital vernier caliper (The L.S. Starrett Co., Athol, MA, USA). The changes in resistance were expressed as the equation: resistance $(\%)=[$ (inhibition zone of control inhibition zone of persistence)/inhibition zone of control] $\times 100$.

\section{Quantitative RT-PCR assay}

An RNeasy Protect Bacteria Mini kit (Qiagen, Hilden, Germany) was used to extract. Briefly, the re-growing cells of $\mathrm{SA}^{\mathrm{WT}}, \mathrm{SA}^{\mathrm{OXA}}, \mathrm{SA}^{\mathrm{CIP}}$, and $\mathrm{SA}^{\mathrm{MDR}}$ treated with twofold MIC of ciprofloxacin were mixed with RNAprotect Bacteria Reagent $(1 \mathrm{ml})$. After centrifugation at $3500 \times g$ for $20 \mathrm{~min}$, the collected cells were lysed with lysozyme-containing buffer and then RNAs were extracted through an RNeasy mini column. The extracted RNAs washed with a Wipe buffer to remove the genomic DNA were mixed with RT buffer, RT primer mix, and a master mixture of reverse transcriptase. After incubation at $42{ }^{\circ} \mathrm{C}$ for $15 \mathrm{~min}$, the master mixture was incubated at $42{ }^{\circ} \mathrm{C}$ for $15 \mathrm{~min}$ and consecutively $95{ }^{\circ} \mathrm{C}$ for 2 min and mixed with each primer $(2 \mu \mathrm{l}$; Table 1$), 2 \times$ QuantiTect SYBR Green PCR Master $(10 \mu \mathrm{l})$, and cDNA $(2 \mu \mathrm{l})$, and RNase-free water $(4 \mu \mathrm{l})$. Each PCR mixture $(20 \mu \mathrm{l})$ was run at $95{ }^{\circ} \mathrm{C}(30 \mathrm{~s}), 45$ cycles of $95{ }^{\circ} \mathrm{C}(5 \mathrm{~s})$, $55{ }^{\circ} \mathrm{C} \quad(20 \mathrm{~s})$, and then $72{ }^{\circ} \mathrm{C} \quad\left(\begin{array}{ll}15 & \mathrm{~s}\end{array}\right)$ using an

Table 1 Primer sequences used in qPCR analysis for Staphylococcus aureus

\begin{tabular}{|c|c|c|}
\hline Gene & Molecular function & Primer name and sequence* \\
\hline $16 \mathrm{~S}$ rRNA & Reference gene & $\begin{array}{l}\text { F: CATGCTGATCTACGATTACT } \\
\text { R: CCATAAAGTTGTTCTCAGTT }\end{array}$ \\
\hline dnak & Chaperone proteins & $\begin{array}{l}\text { F: ACTTCGTCCGGGTTACTCC } \\
\text { R: ACAATGGAACCTACACGCCA }\end{array}$ \\
\hline groEL & Chaperone proteins & $\begin{array}{l}\text { F: CAGTACCACCACCTGCAACA } \\
\text { R: TGCAGCAAGTGAAACAGAGC }\end{array}$ \\
\hline mepR & Efflux pump regulator & $\begin{array}{l}\text { F: TCGATGCACAAGATACGAGA } \\
\text { R: GCGATACGAGTGTTTGTTCC }\end{array}$ \\
\hline norA & Multidrug efflux pump & $\begin{array}{l}\text { F: TCGTCTTAGCGTTCGGTTTA } \\
\text { R: TCCAGTAACCATCGGCAATA }\end{array}$ \\
\hline norB & Multidrug efflux pump & $\begin{array}{l}\text { F: AGCGCGTTGTCTATCTITCC } \\
\text { R: GCAGGTGGTCTTGCTGATAA }\end{array}$ \\
\hline
\end{tabular}

${ }^{*} F$, forward; $R$, reverse
QuantStudio $^{\text {rut }}$ Real-Time PCR System (Applied Biosystems $^{\mathrm{Tw}}$, USA). The comparative method was used to estimate the relative expression levels of genes (Livak and Schmittgen 2001). The $C_{T}$ values of target genes in $\mathrm{SA}^{\mathrm{WT}}, \mathrm{SA}^{\mathrm{OXA}}, \mathrm{SA}^{\mathrm{CIP}}$, and $\mathrm{SA}^{\mathrm{MDR}}$ cells were compared to the $C_{T}$ values obtained from the untreated respective control cells, which was normalized by the reference gene (16S rRNA).

\section{Statistical analysis}

All experiments were carried out in three biological replicates. The obtained data were analyzed by the Statistical Analysis System (SAS) software. The general linear model (GLM) and least significant difference (LSD) procedures were applied to compare among $\mathrm{SA}^{\mathrm{WT}}, \mathrm{SA}^{\mathrm{OXA}}$, $\mathrm{SA}^{\mathrm{CIP}}$, and $\mathrm{SA}^{\mathrm{MDR}}$ persister cells at $p<0.05$.

\section{Results and discussion}

In this study, ciprofloxacin, the gyrase inhibitor, was used to induce persister cells. This study demonstrates the effect of ciprofloxacin treatment on the characteristic features of recovered persister cells formed by various antibiotic-resistant $S$. aureus strains $\left(\mathrm{SA}^{\mathrm{WT}}, \mathrm{SA}^{\mathrm{OXA}}, \mathrm{SA}^{\mathrm{CIP}}\right.$, and $\mathrm{SA}^{\mathrm{MDR}}$ ). Not only antibiotic-resistant bacteria but also antibiotic-tolerant persisters can cause serious health problems, resulting in antibiotic treatment failure (Dörr et al. 2010; Giraud et al. 2017). However, the formation of persister cells and their characteristics still remain unclear. Therefore, in this study, the phenotypic and transcriptomic properties were analyzed to characterize the persistence of various antibiotic-resistant $S$. aureus strains in response to ciprofloxacin.

\section{Induction of persister cells}

The inactivation characteristics of $\mathrm{SA}^{\mathrm{WT}}, \mathrm{SA}^{\mathrm{OXA}}, \mathrm{SA}^{\mathrm{CIP}}$, and $\mathrm{SA}^{\mathrm{MDR}}$ were examined as a function of ciprofloxacin concentration as shown in Fig. 1. The dose-dependent biphasic killing patterns were observed for $\mathrm{SA}^{\mathrm{WT}}$, $\mathrm{SA}^{\mathrm{OXA}}, \mathrm{SA}^{\mathrm{CIP}}$, and $\mathrm{SA}^{\mathrm{MDR}}$ treated with different ciprofloxacin concentrations ranging from zero- to twofold MIC, which were characterized by rapid initial inactivation followed by distinct tailing. The non-growing subpopulation in $\mathrm{SA}^{\mathrm{WT}}, \mathrm{SA}^{\mathrm{OXA}}, \mathrm{SA}^{\mathrm{CIP}}$, and $\mathrm{SA}^{\mathrm{MDR}}$ remained persistent under ciprofloxacin treatment, showing 4-5 $\log$ CFU/ml after twofold MIC of ciprofloxacin treatment (Fig. 1). This suggests that the heterogeneous bacterial populations exposed to bactericidal antibiotics elicit dose-dependent biphasic killing patterns, which are characteristic features of persister cells (Keren et al. 2004; Dörr et al. 2010; Knudsen et al. 2013). To ensure the phenotypic switching to persister cells of $\mathrm{SA}^{\mathrm{WT}}, \mathrm{SA}^{\mathrm{OXA}}, \mathrm{SA}^{\mathrm{CIP}}$, and $\mathrm{SA}^{\mathrm{MDR}}$, the ratios of surviving persister cells after treatment with twofold MIC of ciprofloxacin were measured using a metabolic- 


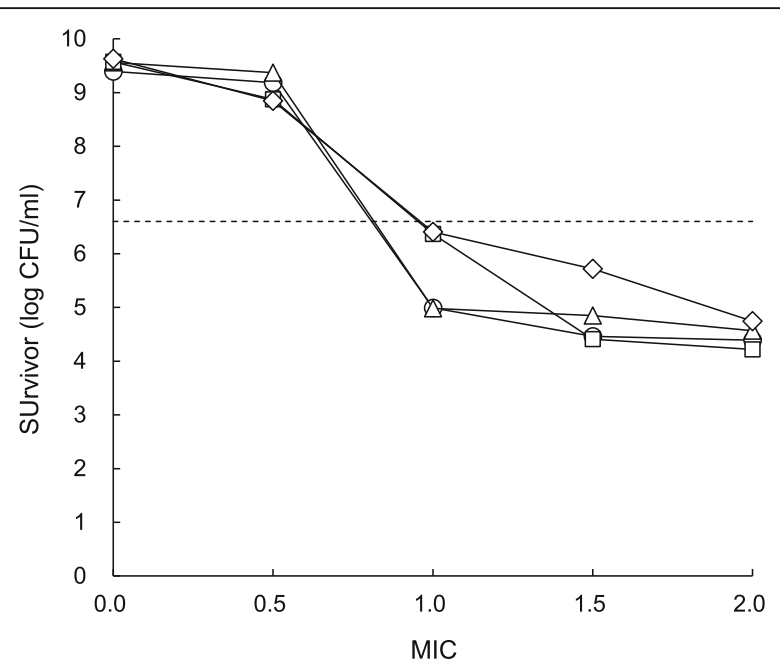

Fig. 1 Survivors of Staphylococcus aureus ATCC 15564 (SA ${ }^{W T}$; circle), oxacillin-induced $S$. aureus (SA ${ }^{\mathrm{OXA}}$; triangle), ciprofloxacin-induced $S$. aureus (SA ${ }^{\mathrm{CIP}}$; square), and clinically isolated multidrug-resistant $S$. aureus CCARM 3080 (SA ${ }^{\text {MDR }}$; diamond) treated with increasing minimum inhibitory concentrations (MICs) of ciprofloxacin at $37^{\circ} \mathrm{C}$. The MICS of ciprofloxacin against SA ${ }^{W T}, S A^{O X A}, S A^{C I P}$, and $S A^{M D R}$ were $2,1,32$, and $32 \mu \mathrm{g} / \mathrm{ml}$, respectively. The dotted line indicates inoculum levels

based assay for eliminating persister cells (Fig. 2). The highest levels of persistence frequency were $\mathrm{SA}^{\mathrm{MDR}}$ (91\%) and $\mathrm{SA}^{\text {OXA }}$ (86\%) after twofold MIC of ciprofloxacin treatment, followed by $\mathrm{SA}^{\mathrm{WT}}(78 \%)$. The least persister cells were induced in $\mathrm{SA}^{\mathrm{CIP}}$ exposed to twofold MIC of ciprofloxacin, suggesting that $\mathrm{SA}^{\mathrm{CIP}}$ was adapted to ciprofloxacin during the pre-exposure to ciprofloxacin. The persistence frequency varied with the classes of antibiotics and the degrees of antibiotic resistance in bacteria (Johnson and Levin 2013). The phenotypic variation is a bacterial survival strategy under unfavorable conditions, leading to the acquired resistance to stresses (Rahman et al. 2017).

\section{Phenotypic resistance to antibiotics}

The relative fitness was estimated by comparing the growth of persister cells to the growth of untreated control cells (Fig. 3). The lowest fitness cost was associated with the development of multidrug resistance that provides survival benefit during the antibiotic treatment (Patra and Klumpp 2013). The highest relative fitness of resistance was observed at $\mathrm{SA}^{\mathrm{CIP}}$ persister cells (0.95), followed by $\mathrm{SA}^{\mathrm{MDR}}(0.70)$ and $\mathrm{SA}^{\mathrm{OXA}}(0.49)$. The least relative fitness of resistance was 0.26 for $\mathrm{SA}^{\mathrm{WT}}$, indicating the highest fitness cost. The antibiotic resistance of the re-growing persister cells of $\mathrm{SA}^{\mathrm{WT}}, \mathrm{SA}^{\mathrm{OXA}}, \mathrm{SA}^{\mathrm{CIP}}$, and $\mathrm{SA}^{\mathrm{MDR}}$ treated with twofold MIC of ciprofloxacin was compared to the untreated control cells (Fig. 4). The recovered persister cells of $\mathrm{SA}^{\mathrm{WT}}$ had high fitness cost (Fig. 3), resulting in the reduced frequency of resistance in the presence of antibiotics (Fig. 4) (Andersson and Hughes 2011). The various antibiotic resistances were observed for the cells recovered from the persisters of $\mathrm{SA}^{\mathrm{WT}}, \mathrm{SA}^{\mathrm{OXA}}, \mathrm{SA}^{\mathrm{CIP}}$, and $\mathrm{SA}^{\mathrm{MDR}}$ exposed to twofold MIC of ciprofloxacin (Fig. 4), indicating the inherent resistance to antibiotics can affect the phenotypic properties of persister cells (Johnson and Levin 2013). The development of cross-resistance was noticeable in the recovered persister cells of $\mathrm{SA}^{\mathrm{OXA}}, \mathrm{SA}^{\mathrm{CIP}}$, and $\mathrm{SA}^{\mathrm{MDR}}$. The recovered persister cells of $\mathrm{SA}^{\mathrm{WT}}, \mathrm{SA}^{\mathrm{OXA}}, \mathrm{SA}^{\mathrm{CIP}}$, and $\mathrm{SA}^{\mathrm{MDR}}$ showed highly enhanced resistance to erythromycin. No changes in the resistance to cephalothin,

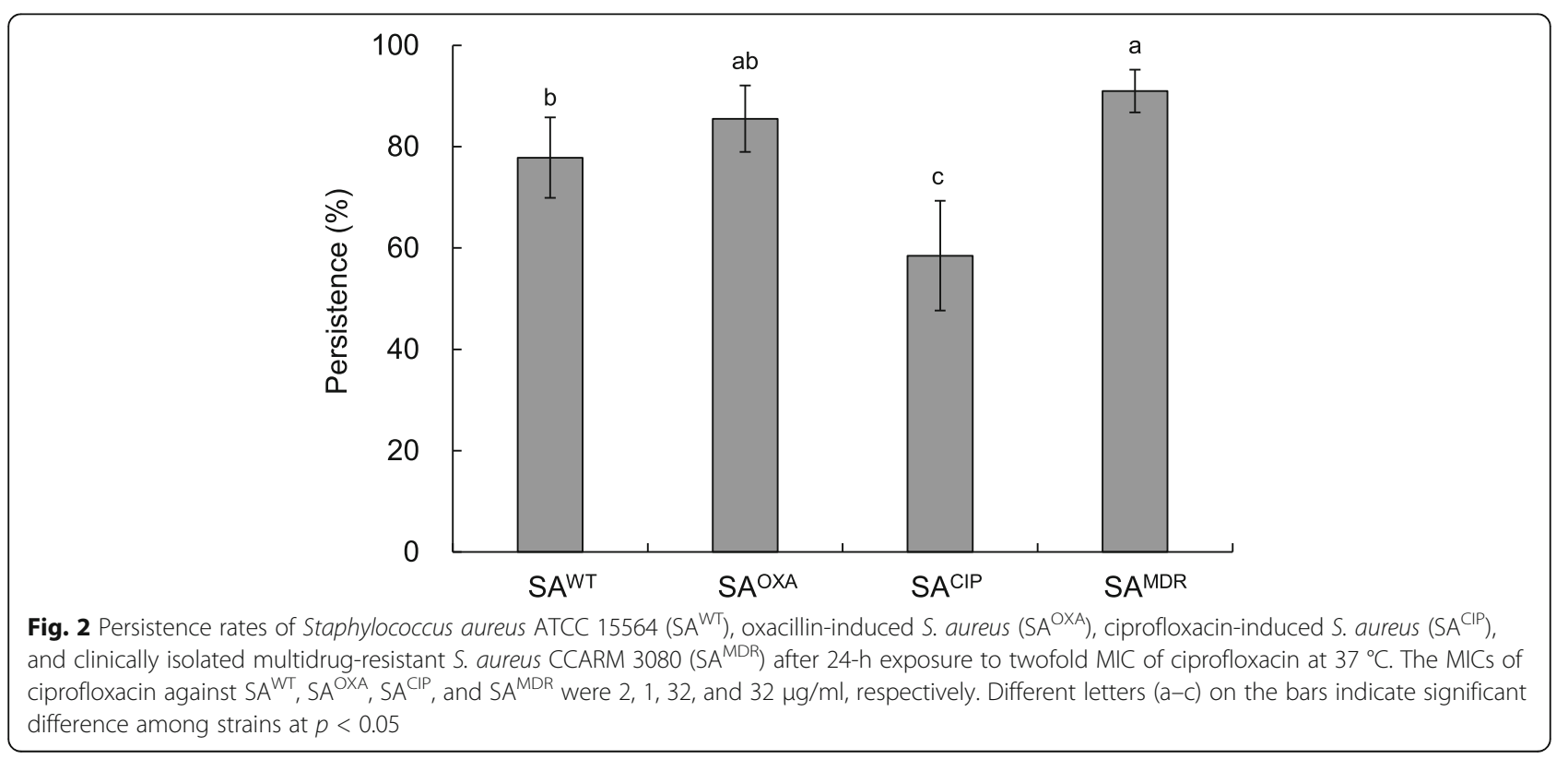




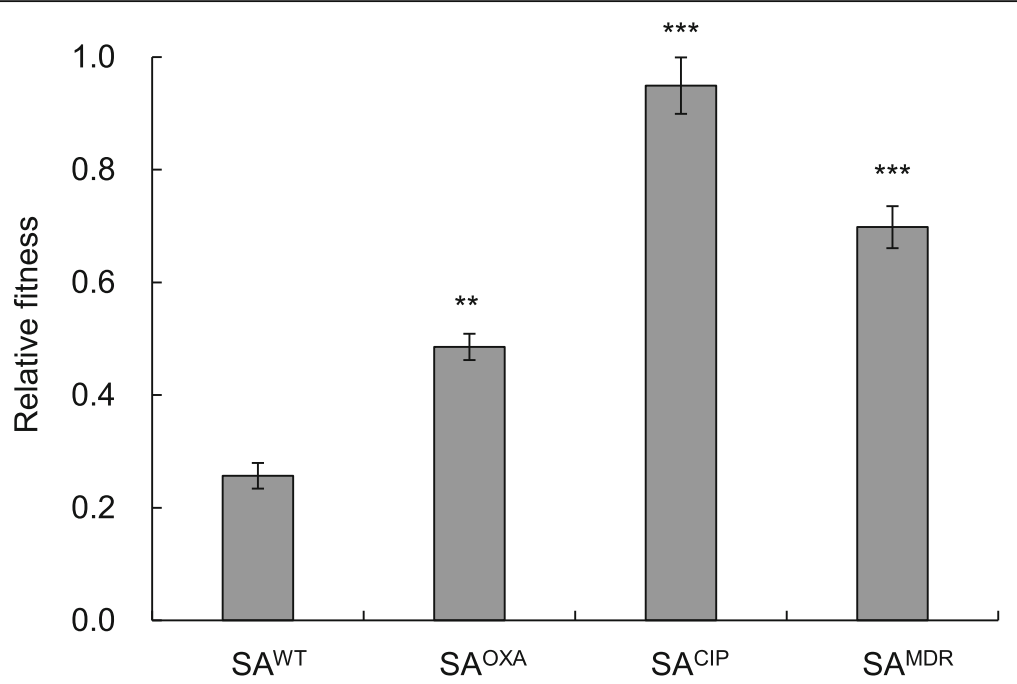

Fig. 3 Relative fitness of Staphylococcus aureus ATCC $15564\left(S A^{W T}\right)$, oxacillin-induced S. aureus $\left(S A^{\text {OXA }}\right.$ ), ciprofloxacin-induced S. aureus (SA ${ }^{\text {CIP }}$ ), and clinically isolated multidrug-resistant S. aureus CCARM 3080 (SAMR) after 24-h exposure to twofold MIC of ciprofloxacin at $37^{\circ} \mathrm{C}$ compared to the respective untreated control. Different letters $(a-d)$ on the bars indicate significant difference among strains at $p<0.05$

ciprofloxacin, and erythromycin were observed for recovered persister cells of $\mathrm{SA}^{\mathrm{MDR}}$ because the untreated control cells previously acquired high-level resistance to those antibiotics. The phenotypic switching can be occurred by non-stress-mediated stochastic and stressmediated responsive mechanisms (Kussell and Leibler 2005). The bacterial survival strategy in the presence of antibiotics is responsible for the increased mutation rates, leading to the development of antibiotic resistance (Li et al. 2017).

The antibiotic-resistant bacteria encoding pre-resistome genes can response to lethal stresses as survival mechanisms, inducing different bacterial phenotypes such as resistance, tolerance, and persistence (Morosini and Cantón 2011; Galán et al. 2013; Brauner et al. 2016). In general, the persister cells formed by environmental stresses are

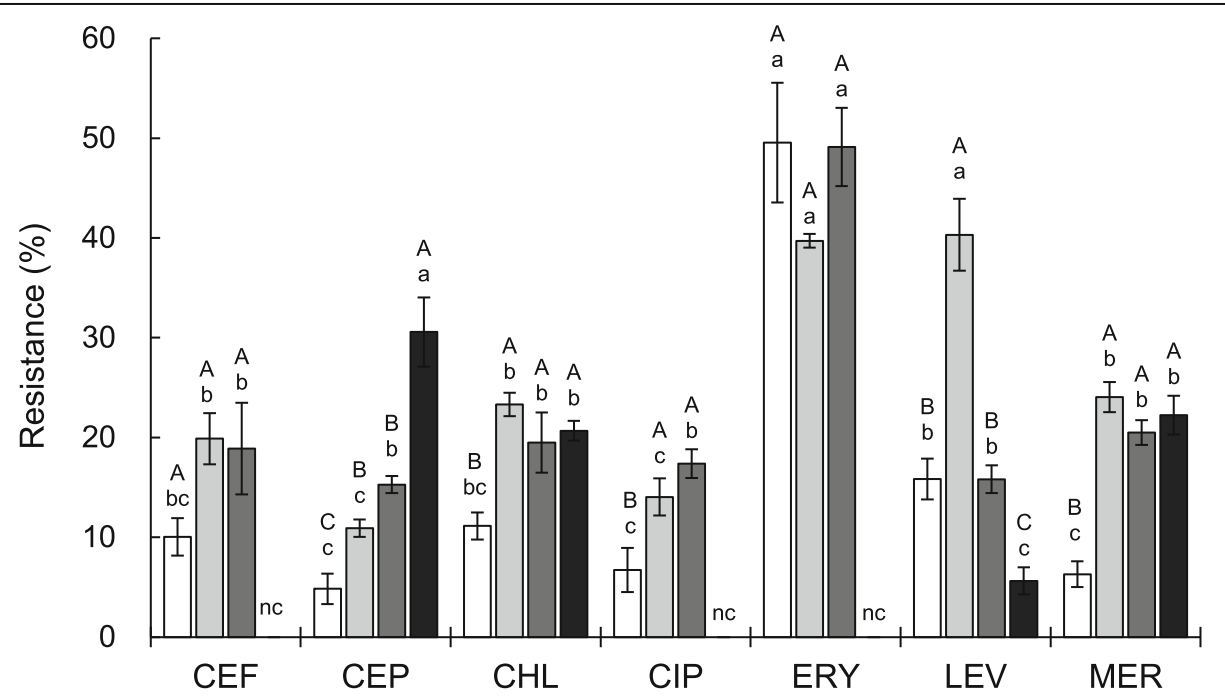

Fig. 4 Percentage resistance of the re-growing cells of Staphylococcus aureus ATCC 15564 (SA ${ }^{\text {WT }}$ ), oxacillin-induced S. aureus (SA ${ }^{\text {OXA }}$ ), ciprofloxacin-induced S. aureus (SA $\left.{ }^{\mathrm{CIP}}\right)$, and clinically isolated multidrug-resistant S. aureus (CARM 3080 (SA ${ }^{\mathrm{MDR}}$ ) exposed to twofold MIC of ciprofloxacin at $37^{\circ} \mathrm{C}$ for $24 \mathrm{~h}$ compared to the respective untreated control. The MICs of ciprofloxacin against SA ${ }^{\mathrm{WT}}, \mathrm{SA}^{\mathrm{OXA}}, \mathrm{SA}^{\mathrm{CIP}}$, and SA ${ }^{\mathrm{MDR}}$ were $2,1,32$, and $32 \mathrm{\mu g} / \mathrm{ml}$, respectively. Different letters $(A-C)$ on the bars within strains are significantly different at $p<0.05$ and different letters $(a-c)$ on the bars within antibiotic are significantly different at $p<0.05$. nc denotes no change in antibiotic resistance. CEF cefotaxime, CEP cephalothin, CHL chloramphenicol, CIP ciprofloxacin, ERY erythromycin, LEV levofloxacin, MER meropenem 
reversible switching to parental state (Fisher et al. 2017; Nicol et al. 2019). The phenotypic changes to persister cells may play an important role in the antibiotic resistance (Rahman et al. 2017). The SOS-induced persister cells of $\mathrm{SA}^{\mathrm{WT}}, \mathrm{SA}^{\mathrm{OXA}}, \mathrm{SA}^{\mathrm{CIP}}$, and $\mathrm{SA}^{\mathrm{MDR}}$ might be formed upon exposure to ciprofloxacin (Marques 2015). The phenotypic and genotypic variations of persister cells regrown in favorable condition are not distinguishable from those of antibiotic-sensitive parent cells (Fisher et al. 2017; Wu et al. 2017; Nicol et al. 2019). Persister cells have been known to be quiescent (Keren et al. 2004; Patra and Klumpp 2013; Wu et al. 2017). In contrast to previous studies, the results obtained from this study point out the variable persistence frequency, relative fitness, and resistance, depending on the nature of antibiotic resistance in $S$. aureus $\left(\mathrm{SA}^{\mathrm{WT}}, \mathrm{SA}^{\mathrm{OXA}}, \mathrm{SA}^{\mathrm{CIP}}\right.$, and $\mathrm{SA}^{\mathrm{MDR}}$ ).

\section{Differential gene expression}

The relative expression of stress-related genes ( $d n a K$ and $g r o E L)$ and efflux pump-related genes ( $m e p R$, nor A, and $n o r B$ ) was observed in the recovered persister cells of $\mathrm{SA}^{\mathrm{WT}}, \mathrm{SA}^{\mathrm{OXA}}, \mathrm{SA}^{\mathrm{CIP}}$, and $\mathrm{SA}^{\mathrm{MDR}}$ treated with twofold MIC of ciprofloxacin compared to respective untreated controls (Fig. 5). The highest expression levels of $d n a K$ and groEL genes were observed in $\mathrm{SA}^{\mathrm{OXA}}$ and $\mathrm{SA}^{\mathrm{MDR}}$, showing more than fourfold increase, whereas the relative expression level of danK in $\mathrm{SA}^{\mathrm{CIP}}$ was decreased by more than twofold (Fig. 5). The DnaK system (dnaK, dnaJ, and grpE) and the GroE system (groES and groEL) prevent stress-induced protein misfolding and aggregation, known as molecular chaperones (Cardoso et al. 2010). The transcriptional levels of dnaK and groEL mRNAs are increased in the presence of antibiotics, resulting in antibiotic resistance (Cardoso et al. 2010). The overexpression of $d n a K$ gene in $S$. aureus can cause increases in the resistance to $\beta$ lactam antibiotics (Singh et al. 2007). The relative expression levels of efflux pump-related genes (mepR, nor $A$, and norB) followed the similar pattern as those of stress-related genes (dnaK and groEL) in $\mathrm{SA}^{\mathrm{WT}}, \mathrm{SA}^{\mathrm{OXA}}$, $\mathrm{SA}^{\mathrm{CIP}}$, and $\mathrm{SA}{ }^{\mathrm{MDR}}$ with the exception of norA gene in $\mathrm{SA}^{\mathrm{WT}}$. The norA gene was suppressed by more than fivefold in $\mathrm{SA}^{\mathrm{WT}}$. The highest expression levels of dnaK, groEL, mepR, norA, and norB were observed in $\mathrm{SA}^{\mathrm{OXA}}$ and $\mathrm{SA}^{\mathrm{MDR}}$, whereas those stress- and efflux pump-related genes were the least stable in $\mathrm{SA}^{\mathrm{CIP}}$. The overexpression of mepR, norA, and norB in $\mathrm{SA}^{\mathrm{OXA}}$ and $\mathrm{SA}^{\mathrm{MDR}}$ (Fig. 4) corresponds to the antibiotic resistance to different classes of antibiotics. This observation indicates a positive relationship between efflux pump activity and persistence (Rahman et al. 2017). The efflux pump systems are still active in persister cells ( $\mathrm{Pu}$ et al. 2016; Rahman et al. 2017). The norA and norB genes encoding multidrug efflux pump belong to the major facilitator superfamily (MFS), which are mainly involved in transport of antibiotics such as norfloxacin and ciprofloxacin using the proton motive force (Costa et al. 2013). NorB plays an important role in the fitness of Staphylococcus aureus, leading to pathogenesis (Ding et al. 2008). The MepR, a regulatory protein, represses

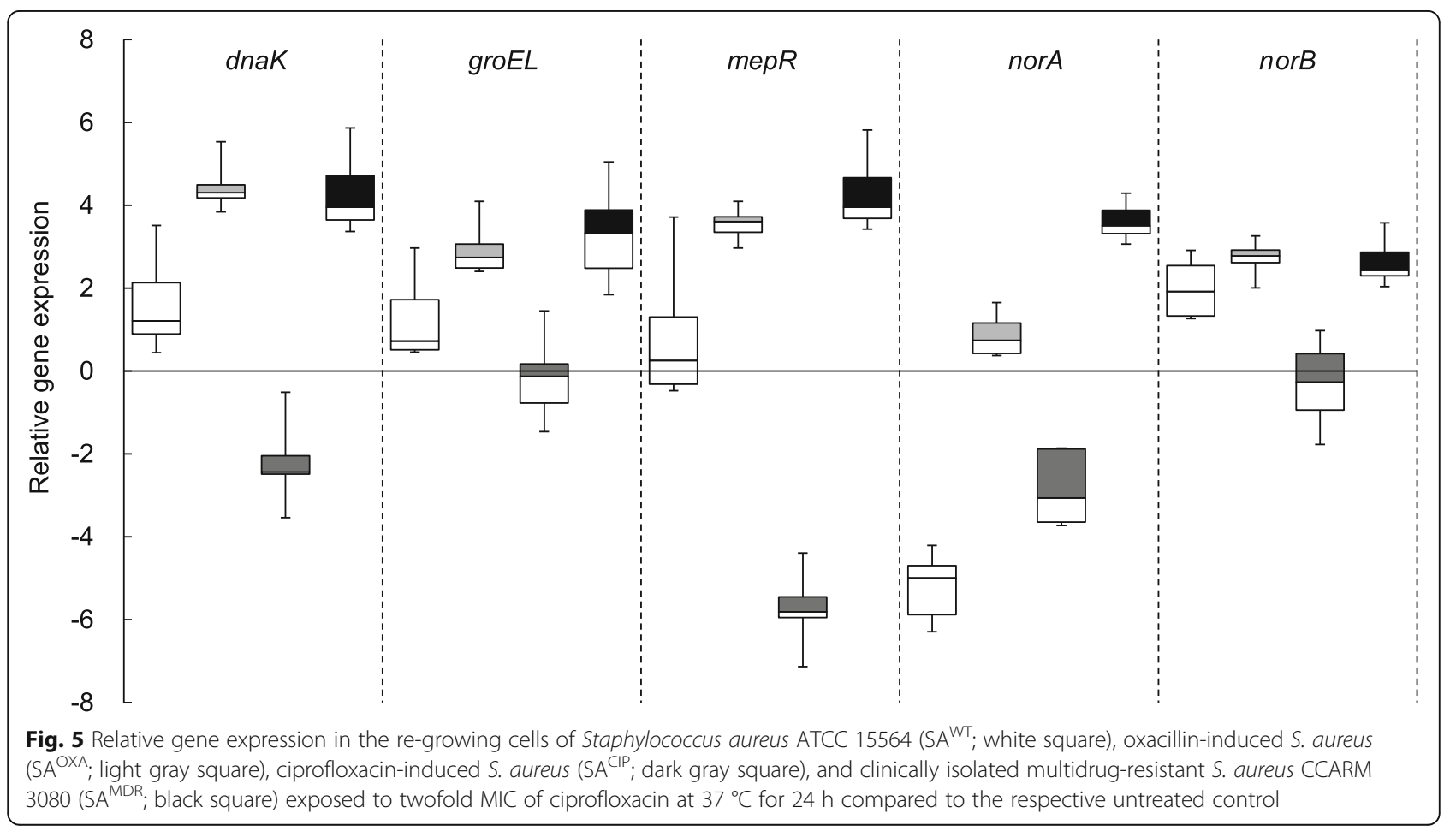


the multidrug transporter (MepA), belonging to the multidrug and toxic compound extrusion (MATE) family (Kaatz et al. 2006; Costa et al. 2013).

In conclusion, this study highlights the dynamics of persister formation in different antibiotic-resistant $\mathrm{SA}^{\mathrm{WT}}, \mathrm{SA}^{\mathrm{OXA}}, \mathrm{SA}^{\mathrm{CIP}}$, and $\mathrm{SA}^{\mathrm{MDR}}$, connecting between antibiotic resistance, tolerance, and persistence. The persister cells formed by different antibiotic-resistant SA ${ }^{\mathrm{WT}}$, $\mathrm{SA}^{\mathrm{OXA}}, \mathrm{SA}^{\mathrm{CIP}}$, and $\mathrm{SA}^{\mathrm{MDR}}$ exhibited the variable patterns of phenotypic and genotypic variations, showing the highest persistence frequencies in $\mathrm{SA}^{\mathrm{OXA}}$ and $\mathrm{SA}^{\mathrm{MDR}}$, the lowest fitness cost in $\mathrm{SA}^{\mathrm{CIP}}$, and the development of multiple antibiotic resistance in $\mathrm{SA}^{\mathrm{OXA}}$ and $\mathrm{SA}^{\mathrm{CIP}}$. The pre-existing antibiotic resistance can affect the phenotypic switching to persister cells of $\mathrm{SA}^{\mathrm{WT}}$, $\mathrm{SA}^{\mathrm{OXA}}, \mathrm{SA}^{\mathrm{CIP}}$, and $\mathrm{SA}^{\mathrm{MDR}}$. The persister cells formed by multidrug-resistant bacteria can easily acquire resistance to additional antibiotic treatment. The level of persistence is associated with the class and dose of antibiotics. The responses of different antibiotic-resistant bacteria to antibiotics can be useful information for designing effective antibiotic treatment regimens. Not only antibiotic-resistant bacteria but also persister cells can cause chemotherapeutic failure. Therefore, this provides valuable insight into the phenotypic and genotypic properties of persister cells.

\section{Publisher's note}

Springer Nature remains neutral with regard to jurisdictional claims in published maps and institutional affiliations.

\section{Acknowledgements}

Not applicable.

\section{Competing interests}

The authors declare that they have no competing interests.

\section{Ethics approval}

This article does not contain any studies involving human participants performed by any of the authors.

\section{Consent to participate}

Not applicable.

\section{Authors' contributions}

JD carried out all experiments and also contributed to the writing the manuscript. SW contributed to the experimental design and statistical analysis. JA conceived of the study and participated in its design and coordination. All authors read and approved the final manuscript.

\section{Funding}

This research was supported by the Basic Science Research Program through the National Research Foundation of Korea (NRF) funded by the Ministry of Education (NRF-2016R1D1A3B01008304).

\section{Author details}

'Department of Medical Biomaterials Engineering and Institute of Bioscience and Biotechnology, Kangwon National University, Chuncheon, Gangwon 24341, Republic of Korea. ${ }^{2}$ Guangdong Provincial Key Laboratory of Aquatic Product Processing and Safety, College of Food Science and Technology, Guangdong Ocean University, Zhanjiang 524088, China.
Received: 12 September 2019 Accepted: 29 January 2020

Published online: 21 February 2020

\section{References}

Andersson DI, Hughes D (2011) Persistence of antibiotic resistance in bacterial populations. FEMS Microbiol Rev 35:901-911

Balaban NQ, Merrin J, Chait R, Kowalik L, Leibler S (2004) Bacterial persistence as a phenotypic switch. Science 305:1622-1625

Birošová L, Mikulášová M (2009) Development of triclosan and antibiotic resistance in Salmonella enterica serovar Typhimurium. J Med Microbiol 58: 436-441

Brauner A, Fridman O, Gefen O, Balaban NQ (2016) Distinguishing between resistance, tolerance and persistence to antibiotic treatment. Nat Rev Micro 14:320-330

Cardoso K, Gandra RF, Wisniewski ES, Osaku CA, Kadowaki MK, Felipach-Neto V, Haus LFA-Á, Simão RCG (2010) DnaK and GroEL are induced in response to antibiotic and heat shock in Acinetobacter baumannii. J Med Microbiol 59: $1061-1068$

CLSI (ed) (2019) Performance standards for antimicrobial susceptibility testing. $29^{\text {th }}$ ed. CLSI supplement M100, Wayne

Conlon BP (2014) Staphylococcus aureus chronic and relapsing infections: evidence of a role for persister cells. BioEssay 36:991-996

Costa SS, Viveiros M, Amaral L, Couto I (2013) Multidrug efflux pumps in Staphylococcus aureus: an update. Open Microbiol J 7:59-71

Deguchi H, Kitazawa K, Kayukawa K, Kondoh E, Fukumoto A, Yamasaki T, Kinoshita S, Sotozono C (2018) The trend of resistance to antibiotics for ocular infection of Staphylococcus aureus, coagulase-negative staphylococci, and Corynebacterium compared with 10-years previous: a retrospective observational study. Plos One 13:e0203705

Ding Y, Onodera Y, Lee JC, Hooper DC (2008) NorB, an efflux pump in Staphylococcus aureus strain MW2, contributes to bacterial fitness in abscesses. J Bacteriol 190:7123-7129

Dörr T, Vulić M, Lewis K (2010) Ciprofloxacin causes persister formation by inducing the TisB toxin in Escherichia coli. PLoS Biology 8:e1000317

Fasani RA, Savageau MA (2013) Molecular mechanisms of multiple toxinantitoxin systems are coordinated to govern the persister phenotype. Proc Nat Acad Sci 110:E2528-E2537

Fernández-García L, Fernandez-Cuenca F, Blasco L, López-Rojas R, Ambroa A, Lopez M, Pascual Á, Bou G, Tomás M (2018) Relationship between tolerance and persistence mechanisms in Acinetobacter baumannii strains with AbkAB toxin-antitoxin system. Antimicrob Agent Chemother 62

Fisher RA, Gollan B, Helaine S (2017) Persistent bacterial infections and persister cells. Nat Rev Microbiol 15:453

Galán J-C, González-Candelas F, Rolain J-M, Cantón R (2013) Antibiotics as selectors and accelerators of diversity in the mechanisms of resistance: from the resistome to genetic plasticity in the $\beta$-lactamases world. Front Microbiol 4:9-9

Giraud E, Rychlik I, Cloeckaert A (2017) Antimicrobial resistance and virulence common mechanisms. Front Microbiol 8

Girgis HS, Harris K, Tavazoie S (2012) Large mutational target size for rapid emergence of bacterial persistence. Proc Nat Acad Sci 109:12740-12745

Harms A, Maisonneuve E, Gerdes K (2016) Mechanisms of bacterial persistence during stress and antibiotic exposure. Science 354:aaf4268

Johnson PJT, Levin BR (2013) Pharmacodynamics, population dynamics, and the evolution of persistence in Staphylococcus aureus. PLoS Genet 9:e1003123

Kaatz GW, DeMarco CE, Seo SM (2006) MepR, a repressor of the Staphylococcus aureus MATE family multidrug efflux pump MepA, is a substrate-responsive regulatory protein. Antimicrob Agent Chemother 50:1276-1281

Keren I, Kaldalu N, Spoering A, Wang Y, Lewis K (2004) Persister cells and tolerance to antimicrobials. FEMS Microbiol Lett 230:13-18

Kester JC, Fortune SM (2014) Persisters and beyond: mechanisms of phenotypic drug resistance and drug tolerance in bacteria. Crit Rev Biochem Mol Biol 49: 91-101

Knudsen GM, Ng Y, Gram L (2013) Survival of bactericidal antibiotic treatment by a persister subpopulation of Listeria monocytogenes. Appl Environ Microbiol 79:7390-7397

Kussell E, Leibler S (2005) Phenotypic diversity, population growth, and information in fluctuating environments. Science 309:2075-2078

Lewis K (2007) Persister cells, dormancy and infectious disease. Nat Rev Micro 5: $48-56$

Lewis K (2010) Persister cells. Ann Rev Microbiol 64:357-372 
Li J, Xie S, Ahmed S, Wang F, Gu Y, Zhang C, Chai X, Wu Y, Cai J, Cheng G (2017) Antimicrobial activity and resistance: influencing factors. Front Pharmacol 8

Livak KJ, Schmittgen TD (2001) Analysis of relative gene expression data using real-time quantitative PCR and the $2^{-\Delta \Delta C T}$ method. Method 25:402-408

Lowy FD (1998) Staphylococcus aureus infections. N Eng J Med 339:520-532 Marques CNH (2015) Isolation of persister cells from biofilm and planktonic populations of Pseudomonas aeruginosa. Bio-protocol 5:e1590

Morosini M-I, Cantón R (2011) Emergence and spread of antibiotic resistance following exposure to antibiotics. FEMS Microbiol Rev 35:977-991

Nicol M, Mlouka MAB, Berthe T, Di Martino P, Jouenne T, Brunel J-M, Dé E (2019) Anti-persister activity of squalamine against Acinetobacter baumannii. Int J Antimicrob Agent 53:337-342

Patra P, Klumpp S (2013) Population dynamics of bacterial persistence. PLoS One 8:e62814

Pu Y, Zhao Z, Li Y, Zou J, Ma Q, Zhao Y, Ke Y, Zhu Y, Chen H, Baker MAB, Ge H, Sun Y, Xie XS, Bai F (2016) Enhanced efflux activity facilitates drug tolerance in dormant bacterial cells. Mol Cell 62:284-294

Rahman T, Yarnall B, Doyle DA (2017) Efflux drug transporters at the forefront of antimicrobial resistance. Eur Biophys J 46:647-653

Sahukhal GS, Pandey S, Elasri MO (2017) msaABCR operon is involved in persister cell formation in Staphylococcus aureus. BMC Microbiol 17:218

Sakoulas G, Eliopoulos GM, Moellering RC Jr (2006) Adaptation of methicillinresistant Staphylococcus aureus in the face of vancomycin therapy. Clin Infect Dis 42:S40-\$50

Singh VK, Utaida S, Jackson LS, Jayaswal RK, Wilkinson BJ, Chamberlain NR (2007) Role for dnak locus in tolerance of multiple stresses in Staphylococcus aureus. Microbiol 153:3162-3173

Wu S, Yu P-L, Flint S (2017) Persister cell formation of Listeria monocytogenes in response to natural antimicrobial agent nisin. Food Cont 77:243-250

Ready to submit your research? Choose BMC and benefit from:

- fast, convenient online submission

- thorough peer review by experienced researchers in your field

- rapid publication on acceptance

- support for research data, including large and complex data types

- gold Open Access which fosters wider collaboration and increased citations

- maximum visibility for your research: over $100 \mathrm{M}$ website views per year

At $\mathrm{BMC}$, research is always in progress.

Learn more biomedcentral.com/submissions 